Studia Anglica Posnaniensia 47/4, 2012

doi: 10.2478/v10121-012-0015-7

\title{
LITERATURE
}

\section{THE GOD OF THE MIDDLE ENGLISH CLEANNESS AND HIS EROTIC EXHORTATIONS OF PURITY}

\author{
PIOTR SPYRA
}

University of Łódź

\begin{abstract}
The Middle English Cleanness is a poem unique in the medieval context in that it couples its homophobic discourse with a powerful vindication of sexual pleasure and its role in relationships without referring to the procreative telos of marriage. In fact, Cleanness does not even stress that the only proper arena for erotic desire is the marriage bed, with the narrator emphasising the mutuality of pleasure instead. The article investigates the text's rhetorical interplay between the vilification of homosexuals and the divine endorsement of heterosexual lovemaking. Going beyond the established critical consensus on the issue, it argues that the contrast between the two serves not only to allow the author to vent his homophobic prejudice but also connects with the epistemological concerns of Pearl, the text that precedes Cleanness in the Cotton Nero A.x manuscript.
\end{abstract}

The Middle English Cleanness is a poem remarkable for its presentation of God, a ruthless master who easily succumbs to ire and does not hesitate to wreck the earth in a fit of anger, only to suffer from pangs of conscience afterwards. The most puzzling thing about him is that in praising the virtue of cleanness he uses an overtly eroticising discourse, going as far as to claim that the joys of lovemaking almost equal those of Paradise. As David Wallace (1991: 95-96) rightly observes, "[i]t is ... remarkable to encounter a medieval God who thinks out loud, who is seized with sudden fits and longings, who is said to forget his own courteous manners and waxes eloquent on the joys of erotic pleasure". The narrator's attitude in propounding his views is equally baffling: the text couples an exhortation of purity with a surprising reference to the alleged cleanness of Jean de Meun's continuation of the Roman de la Rose, and pre- 
sents the biblical Lot, who is willing to sacrifice his daughters' virginity to assuage an angry mob, as one of the few righteous men that deserve to escape the wrath of the deity. Despite the appearance of contradiction, however, the homiletic discourse of the poem is governed by a strict logic that serves the sermonist's didactic aims. In line with the established critical consensus on the issue, the argument of this article stresses the fact that God's endorsement of heterosexual lovemaking arises out of his condemnation of homosexual acts. Going beyond the issue of sexuality as such, however, it posits a reading that links the thematic concerns of Cleanness with those of its manuscript companion, Pearl. Through the study of the nature of man's relationship with Christ as it emerges from the poem, the argument that follows attempts to recover the logic of the narrative and reconcile the differences between the three biblical episodes that Cleanness relates. Much as the investigation of the poem's didactic aims ultimately leads one to consider matters of epistemology, however, it is the issue of sexuality that has to be addressed first, for the poem's treatment of carnal pleasures "includes one of the most powerful accounts of the joys of love in all of English poetry" (Keiser 1997: 2) and clearly stands out in the context of the medieval homiletic tradition, or even medieval literature as such.

That God should refer to the pleasures of the body in amicable or even encouraging words is particularly striking if one considers the general structure and message of Cleanness. The poem consists of three main episodes, each presenting the Maker, incited to uncontrollable wrath, in the act of destroying the unclean. Both the haste with which he acts and the sheer scale of destruction leave little room for doubt that the God of Cleanness hates impurity to a degree reaching beyond man's comprehension. In the first episode, presenting the biblical story of the Flood, the phrasing of the text suggests that without any deliberation or forethought, acting on a sudden impulse only, he literally unmakes the world, prompted by the wickedness of the antediluvian population. When "felle temptande tene towched his hert" (Cleanness 283) ${ }^{1}$ he loses control and goes so far as to undo the division of the "waters which were under the firmament from the waters which were above the firmament" (Genesis 1.7):

Was no brymme that abod unbrosten bylyve;

The mukel lavande logh to the lyfte rered.

Mony clustered clowde clef alle in clowtes,

Torent uch a rayn ryfte and rusched to the urthe,

Fon never in forty dayes, and then the flod ryses,

Overwaltes uche a wod and the wyde feldes;

Henceforth abbreviated to $C$. All quotations from the poem come from Cawley, Arthur Clare - John J. Anderson (eds.). 1976. Pearl, Cleanness, Patience, Sir Gawain and the Green Knight. London: Dent. 
For when the water of the welkin with the worlde mette,

Alle that deth moght dryye drowned therinne

(C 365-372).

When the waters of the sky meet with the rising flood, all mortal creatures die, completing thus the act of Un-Creation. The fate of Sodom in the poem's second episode is not much better, for although God promised never to destroy the whole world again ${ }^{2}$, his wrath, focused on the area of the city and its immediate surroundings ${ }^{3}$, drives him to commit a similar act of total annihilation, and his "vengaunce voyded thise places" (C 1013).

The third episode is more problematic, as it seems to undermine the nature of the sin that enrages God to such an extent. The story of Belshazzar's Feast includes no overt sexual elements, in contrast to the preceding two episodes, for although the emperor's feast indeed has an orgiastic character, with the presence of his concubines mentioned, the narrative's focus is on the temple vessels and their use for profane practices, rather than on the promiscuity of the gathering. While both the antediluvians and the Sodomites are punished for their homosexual acts, Belzhazzar's fault lies in mishandling sacred objects dedicated to God. The common denominator of all three episodes is, in fact, broadly understood defilement, and not sexual impurity, much as the reader's initial impression may suggest otherwise. It is significant that the poem opens with the biblical parable of the Wedding Feast in which the Lord throws out an ill-clad guest from his chambers in a sudden fit of anger not much different from the Creator's ireful outbursts. The dirty clothes of the guest challenge and defile the decorum of the feast, and all three major episodes follow upon this notion - the stories of the Flood and of Sodom revolve around people guilty of defiling their bodies, and the final section of the poem presents Belshazzar in the act of defiling the sacred vessels of the Hebrews. That the third episode is not to be seen as essentially different from the earlier two is also suggested by the fate which befalls Belshazzar. Though the destruction brought upon by God is now even more focused and targets the Babylonian emperor only, leaving even his close advisors unscathed, he too is unmade by the Maker:

The kyng in his cortyn was kaght bi the heles,

Feryed out bi the fete and fowle dispysed,

That was so doghty that day and drank of the vessayl;

Now is a dogge also dere that in a dych lygges

(C 1789-1792).

2 "Now, Noe, no more nel I never wary / Alle the mukel mayny-molde for no mannes synnes" (C 513-514).

3 Although the narrative presents the story of the city of Sodom only, it acknowledges that the area laid waste included as many as five cities $(C$ 1015). 
The comparison of Belshazzar with a dog dehumanises him, reducing him to a piece of flesh, a mass of raw material no longer animated by the spirit of life, and the implied suggestion that the Medes disposed of the body in a ditch reinforces the notion of unmaking, for the emperor returns to the mud and ashes from which he originates.

The distinct character of the third episode makes it difficult to maintain that the narrative's main goal is to condemn homosexual love, yet that is how some critics have attempted to make sense of the eroticising speech of God, which deserves to be quoted here in its entirety:

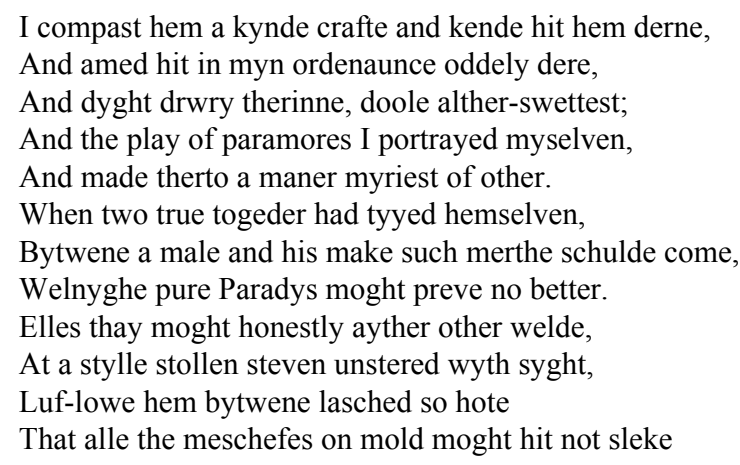

(C 697-708).

What is really surprising is that in this vindication of heterosexual desire, the text does not resort to the teleology of the sexual act, and, seen "from the perspective of medieval theology, the absence of the procreative argument from this passage is nothing short of astonishing" (Calabrese and Eliason 1995: 254). In fact, there does not seem to be much argumentative force in this passage at all, and in this respect, it is typical of Cleanness as a whole. Though the narrator ends the poem by saying that "thus upon thrynne wyses" he has showed how uncleanness incites God to wrath $(C$ 1805), and implies with this phrase that he has enumerated several arguments to prove his point, rather than a line of reasoning what the readers of Cleanness really experience is being preached at. Anderson (2005: 87) points to the following lines, which encapsulate the text's magisterial attitude:

Wich are thenne thy wedes thou wrappes the inne,

That shal schewe hem so schene, schrowde of the best?

Hit arn thy werkes wyterly that thou wroght haves

(C 169-171).

This rhetorical question leaves the readers no room to doubt the narrator's pontificating pronouncements, nor does it give them the time to ponder upon the 
question posed. This strategy is maintained throughout the poem. Instead of using logical arguments, Cleanness proves its point by lengthy, repetitive yet vigorous reiterations of its key message. Time and again the readers see God react to impurity with uncontrollable rage, yet despite the variety of biblical illustrations, the narrator does not really develop his main idea; he merely reprises his homiletic instruction under a new biblical guise, staying within the same pattern of sin and God's angry response. There is nothing to consider here or to discuss, and the wrath of God is a self-evident fact one simply has to take into account.

This affective rhetoric is clearly at work in God's speech, for what justifies the sexual act instead of procreation is pleasure. God speaks of a flame of desire so intense that it shields the lovers from all the mischiefs of the world $(C 707-$ 708), fashioning for them a divinely ordained paradisiacal universe free from trouble or sorrow. This is not much different from John Donne's famous line in "The Good Morrow" in which the speaker claims that true love "makes a little room an everywhere"; the hyperbolic character of such a statement strongly reinforces the appeal to emotions rather than reason. Calabrese and Eliason point out that the poem "revises the usual medieval hierarchy of sexual experience" within which it is "virginity, not marriage [that] affords the individual protection against "alle the meschefes on mold" (255); God's "ordenaunce" given in his speech states quite openly that this protection springs not just from any aspect of marital life but specifically the physical "merthe $[\ldots]$ bytwene a male and his make". Apart from pleasure, the only other argument found in the passage is that God willed it so. The Maker creates the impression of taking great pride in endowing humankind with such a wonderful gift, and in stressing that "the play of paramores I portrayed myselven", he emphasizes his deep personal involvement in its creation and qualifies it with the full force of his divine endorsement. In this too, the text underlines the fact that God's pronouncement admits no questioning.

That such a curious approach to the sexual act has something to do with the condemnation of the antediluvians and the Sodomites has by now become generally accepted in criticism. In her 1997 book-length study of the poem's involvement with medieval homophobia, Elizabeth B. Keiser explains that "Cleanness's legitimation of heterosexual desire is linked to, and to a degree depends logically upon, a rhetoric of intolerance against men who take each other for lovers" (1997: 3); the text elaborates so much on the appropriateness of heterosexual acts in order to allow God's "fury against the Sodomite men [... to be] rationalized as appropriately totalitarian in intensity and scope" (1997: 2). Calabrese and Eliasion (1995: 270) see a strong bond between what they call "the rhetoric of blame" and "the rhetoric of praise," arguing that "since the poet

$4 \quad$ Emphasis mine, PS. 
predicates his condemnation on disgust, he must predicate his praise on pleasure". Indeed, in its vilification of homosexuals the text predictably fails to provide any rational arguments. In line with its usual practice, it only "summons up feelings of physical revulsion" (Calabrese and Eliason 1995: 262), as when it points out that as soon as Adam's descendants stooped so low as to commit homosexual acts $^{5}$, their natural beauty withered, giving way to a sort of foulness that the devils themselves found attractive:

\footnotetext{
And those lykkest to the lede [Adam] that lyved next after;

Forthy so semly to see syten wern none. ...

And thenne founden thay fylthe in fleschlych dedes,

And controeved again kynde contraré werkes,

And used hem unthryftyly uchon on other,

And als with other, wylsfully, upon a wrange wyse.

So ferly fowled her flesch that the fende loked

How the deghter of the douthe wern derelych fayre,

And fallen in felawschyp with hem on folken wyse,

And engendered on hem jeauntes with her japes ille
}

(C 261-262, 265-272).

The text only hints at the monstrosities conceived thus through the conjugation of devilish malice ("japes ille") and human promiscuity, and the implication of the sort of abominations that walked the face of the earth due to man's wicked contrivings once again engages the readers' emotions rather than intellect. The text stresses the repulsive character of using God-given sexuality "upon a wrange wyse" rather than its undesirable logical consequences. Sterility never makes it into the array of arguments listed by the narrator in his diatribe against homosexuality ${ }^{6}$, for the text condemns by engaging emotions, not by providing arguments. Admittedly, the wasteland of the Dead Sea that remains after God annihilates Sodom represents this sterility in a symbolic way, but the narrator never makes overt use of this argument in his expositions. Calabrese and Eliason's (1995: 263) pioneering study thoroughly investigates the poem's vocabulary of indigestion, nausea and revulsion, pointing at a rhetorical question Cleanness posits with the full force of its authoritarian discourse: "what better way to deal with slime than to wash it away?"

$5 \quad$ At this point in the narrative the text does not specify yet what exactly constitutes the "fylthe of the flesch" ( $C$ 202) that incites God to drown the world in a fit of rage. Only later, once the exact character of the Sodomites' sin is given, does the text of Cleanness reveal unequivocally that the city of Sodom was destroyed "for this ilk evel" $(C 573)$ that sent the antediluvians to their doom. For an overview of how Cleanness presents the Flood and Sodom stories as two exempla of the same sin, see Keiser (1997: 41-48).

6 Given that in medieval culture "the legitimating motives for intercourse are primarily procreational" (Keiser 1997: 63), this is quite striking. 
The conclusions that most critics reach is that "the poet's praise of married love arises almost accidentally from his treatment of homosexuality, rather than from an intentional and programmatic revision of sexual theory" (Calabrese and Eliason 1995: 266). God's "erotic discourse ... justifies [his] homophobic wrath" (Keiser 1997: 2), and this is the purpose that it ultimately serves, being "an accidental offshoot of the logically prior choice to construct sodomy in terms that stress its repulsive filthiness rather than its irrational sterility" (Keiser 1997: 5). ${ }^{7}$ In his overview of the Pearl manuscript directed not just at scholars but also students and general readers, J. J. Anderson (2005: 106) explains that it is "the narrator's desire to make the cleanness / uncleanness contrast as sharp as possible that drives him to take up unorthodox positions", and "the implication of [God's speech] is that God sees the joys of his gift of heterosexual sex as so great that his fury at men's meddling with his gift is understandable" (Anderson 2005: 107). This commonly shared critical contention is founded on the assumption that the poet's main concern was to find a proper expression of his homophobic attitude and that this is the rationale behind the structure of the whole narrative.

If one abstracts from the final episode of Cleanness, much suggests that the entire narrative and the liberties it sometime takes with its biblical source serve the single purpose of making homosexuality seem as repulsive as possible. This is clearly evident if one considers the motivation behind Lot's offer to prostitute his daughters. The offer is made as, together with his angelic guests, Lot finds himself besieged in his own house by a mob of angry Sodomites, eager to practise their wicked ways with the city's new visitors. Lot cares little for his daughters' honour since his main concern is to protect his guests from homosexual rape, which is why he openly urges the Sodomites to "letes my gestes one" and use the daughters instead in any way they please. Not only does he hope that offering the girls will resolve the standoff, but he is also trying to find a longterm solution to the problem he faces in the city. "I schal kenne yow by kynde a crafte that is better" ( $C$ 865) is how he begins his speech, which indicates that his goal is not just to assuage the anger of the mob but also to make them change their wicked ways. Significantly, this particular motivation is missing from original Genesis story ${ }^{8}$, where Lot does not attempt to reform the Sodomites. The biblical text is thus altered in Cleanness to communicate how unacceptable homosexual behaviour is. With the exception of the Belshazzar episode, numerous details of the text can be explicated in this manner, yet the shifting of the emphasis away from sexual offences in the story of the Babylonian ruler makes it difficult to accept homophobia as the driving force behind the totality of the poem.

Keiser summarises the argument of Calabrese and Eliason in these words. Cf. Genesis 19.6-9. 
A closer investigation of the logic of the textual arguments at play in Cleanness reveals that the vilification of homosexual acts serves a greater rhetorical purpose, one that lies at the core of all four poems of the Cotton Nero A.x manuscript and reaches its apex in the text of the preceding Pearl; its goal is to underline the great divide between man and God and to heighten the sense of a fundamental gulf between the mortal world of change and decay and the realm of immutable divine perfection. Explored extensively in Pearl's contrast between the earthly garden and the jewel-like landscape of its oneiric vision, this contrast is also a latent driving force behind the text of Cleanness. To trace the strategy of the text in arguing for the immensity of this great divide, one needs to consider the narrator's allusion to the Roman de la Rose and his admonition to "confourme ... to Kryst":

For Clopyngnel in the compas of his clene Rose, Ther he expounes a speche to hym that spede wolde Of a lady to be loved: 'Loke to hir sone

Of wich beryng that ho be, and wych ho best lovyes;

And be ryght such in uch a borghe, of body and of dedes,

And folw the fet of that fere that hou fre haldes.

And if thou wyrkkes on this wyse, tagh ho wyk were,

Hir schal lyke that layk that lyknes hir tylle.'

If thou wyl dele drwrye wyth Dryghtyn thenne,

And lelly lovy thy Lorde and his leef worthe,

Thenne confourme the to Kryst, and the clene make,

That ever is polyced als playn as the perle selven

(C 1057-1068).

What is quite troubling here is that while the narrator's lack of critique with regard to Lot's offer clearly springs from the overall strategy of advancing any kind of behaviour as better, or less repulsive, than homosexual acts, presenting Jean de Meun's poem as "clene" has little to do with this rhetoric. The mention of the "clene Rose" is far more difficult to rationalise by recourse to the poet's homophobia than the passage about Lot, though not everyone sees this reference as different or problematic; Anderson (2005: 102-103), for instance, reads the remark as suggestive of "the narrator's willingness to plunder whatever he can find to make his point", even if it means appealing to a text that "is not clean at all but a known exposé of the worldly mores of courtly society". Indeed, since God himself tends to get quite emotional and exuberantly positive about praising the joys of heterosexual love, there is no reason to condemn the sexual explicitness of de Meun's poem within this rhetorical framework.

Despite the semblance of interpretive clarity which Anderson's explanation creates, however, the Roman is clearly not mentioned here, as Lot's offer was, 
to provide a neat contrast between proper and improper sexuality, for instead of elaborating on the cleanness of heterosexual acts, the passage focuses on one's relationship with Christ, depicted here in terms of courtly love. To use Calabrese's and Eliason's phrases, it does not engage the rhetoric of praise directly, so it cannot really function as a legitimate part of the rhetoric of blame which, in the Lot story, makes the poet claim that even heterosexual prostitution is better than homosexuality. What is more, the passage where the Roman is alluded to is quite perplexing also because of the way it delineates the exact nature of one's relationship with Christ:

\begin{abstract}
The ... passage opens with the not uncommon suggestion of sexual romance as a metaphor for humanity's relationship with God. Though popular in many religious writings (especially lyric poems and mysticism), such a metaphor is nonetheless startling in a poem that stresses sexual purity. Furthermore, the poet does not merely speak of humanity's love for God as romantic (an analogy so commonplace as to carry little force), he even uses an overtly erotic word
\end{abstract}

(Prior 1994: 67).

The word is "drwrye", the same that may also be found in the final of the Cotton Nero poems, where it features in the love-bantering between Sir Gawain and Lady Bertilak. Not only does it stand out in a poem devoted to purity, but the use of the metaphor of sexual romance may strike attentive readers as, in fact, going against the poet's condemnation of same-sex relationships. It is important to notice that the narrator makes use of courtly love as a metaphor not for humanity's relationship with God in general, but specifically with Christ. It is clear from the Roman passage that Christ is to be imitated by his followers just as a lover transforms himself to be more like his lady in order to win her heart and gain her acceptance. Given the predominantly male quality of medieval readership, or, assuming oral production of the poem, of its likely audience ${ }^{9}$, in a certain sense the metaphor thus surprisingly equates a particular kind of samesex relationship with heterosexual lovemaking, and gives one's relationship with Christ not only homosocial but even homosexual overtones.

A comparison of the Roman passage with the sins of the Sodomites reveals distinct similarities:

\footnotetext{
Given the elaborate formal patterning which emerges only if one considers the Cotton Nero A.x manuscript as a whole and follows the order of the four poems it contains (see Condren 2002 and Prior 1994), it is plausible to argue that, apart from being suited, or perhaps even destined, for oral production, the poems were also intended to be read in silence off the manuscript page. The full macro-text would thus have been available to few readers, most of them male.
} 
Thay han lerned a lyst that lykes me ille, That thay han founden in her flesch of fautes the werst; Uch male mas his mach a man as hymselven, And fylter folyly in fere on females wyse

(C 693-696).

There are two basic components to God's accusation; what drives the Maker to anger is not only the very fact of males taking other males as mates $(C 695)$ but also the dismantling of gender roles which such acts entail ( $C$ 696). A distinct feature of the Sodomite relationships, one that allows the narrator to label them as "werkes contraré again kynde" is that at least one of the parties involved acts in a female fashion ("on females wyse"), taking up the role of the female lover. That is exactly how the metaphor in the Incarnation passage works, however. In the analogy suggested by the narrator in his quotation from de Meun, Christ takes up the role of the lady. In one sense, it is a conventional appeal to the faithful to imitate Christ, a notion common in the Cleanness-Poet's day. ${ }^{11}$ The courtly love metaphor itself is not unusual either. However, the way this passage renders effeminate the relation between the male reader and Christ ostensibly challenges the vilifying force of the narratorial homophobic tirade and suggests that it is more plausible to see Cleanness as something more than a critique of homosexuality to which all the exigencies of the text are ultimately subordinated

It is obviously difficult to believe that the poet actually saw the Sodomite relationships and the faithful Christian's individual bond with Christ as anything but wildly dissimilar, yet for some reason he hints at the fact that on a certain level of logic they both share the same characteristics, which in the former case invite censure of the highest proportions, whereas in the latter they are actually seen as desirable. The poet's strategy may best be explicated by a reference to an analogous set of rhetorical tactics underlying the phallocentrism of Western culture. As Jonathan Culler explains, within phallocentric discourse the praise of an ideal woman is very often a ploy that makes it possible to denigrate actual women, who can never live up to the posited ideal:

discussions of woman that appear to promote the feminine over the masculine ... celebrate the woman as goddess ... and invoke a metaphorical woman, in comparison with which actual women will be found wanting. Celebrations of woman or the identification of woman with some powerful force or idea-truth as a woman, liberty as a woman, the muses as women-identify actual women as mar-

10 This expression is actually used to qualify the sins of the antediluvians, though by extension it also pertains to the Sodomites.

11 The famous Imitation of Christ by Thomas à Kempis was written only about 30-50 years after the Cotton Nero poems. 
ginal. Woman can be a symbol of truth only if she is denied an effective relation to truth, only if one presumes that those seeking truth are men. The identification of woman with poetry through the figure of the muse also assumes that the poet will be a man. While appearing to celebrate the feminine, this model denies women an active role in the system

(Culler 1983: 166-167).

By the same token, homosexual activity is all the more hideous because in a certain sense it reflects, and thus debases, the imitation of Christ. It is not only a sin against nature but also a mockery of true communion with the Saviour. While celebrating the male reader's relationship with Christ, the text thus dismisses all forms of behaviour which bear metaphorical relation to it, however distinct and unlike the imitatio Christi they should be. Cleanness never compares homosexuality and the imitation of Christ directly, only hinting at the potential correspondence between the two, and it nowhere suggests that one should take the parallelism between them as valid, or see them as essentially connected. Quite the contrary: it is not surprising that given the outrageous and blasphemous character of this analogy, never to be made explicitly but only implied in the text, the poem advocates a complete annihilation of those who engage in homosexual practices. Whereas phallocentric rhetoric aims to marginalise women, the homophobic discourse of Cleanness argues for a total annihilation of homosexuals.

The very idea of positing such an analogy may seem unthinkable, yet in the context of the Cotton Nero manuscript it fits perfectly into the contrastive scheme introduced in the text of Pearl, which immediately precedes Cleanness. Pearl's main contrast is that between permanence, as symbolised by the crystalline landscape of the dream vision, and death and decay, illustrated by the withering flowers of the earthly garden. It is a contrast between earthly struggle, seen in the hierarchical ordering of the human world which the Dreamer time and again invokes, and the plenitude of heaven that, as the Parable of the Vineyard shows, admits of no gradation. It is predicated upon a fundamental dichotomy between the two planes of existence, whose similarity is only illusory. Cleanness, continuing this line of reasoning, pushes the extent of the great gulf between heaven and earth to its limits. By hinting at the uneasy analogy between the imitation of Christ and the sins of the Sodomites and the antediluvians, an analogy so gruesome that it is never to be pursued to its conceptual fruition, it leaves the readers no doubt as to the fact that despite the appearance of similarity the mortal plane and the realm of heavenly perfection are truly worlds apart. It is not without its significance that the reference to the Roman de la Rose begins what is generally referred to in criticism as the "Incarnation passage" and explicitly mentions Christ. The miracle of the incarnation of the Son of God invites the members of the Christian community to consider the ways in which the Saviour brought his human and divine natures together, conflating them for the sake of humankind's redemption. Clean- 
ness, on the other hand, urges them not to seek analogies between heaven and earth where there are none, stressing in this manner the uniqueness and wonder of Christ's sacrifice, as well as the extremity of the great gulf separating man and God which Christ, in his divine mercy, bridged for man's sake. The lesson of Cleanness is quite clear: when a man follows Christ, who adopts in this relationship of faith the standard courtly role of the imitated lady, the Rose is perfectly "clene"; when two men "fylter folyly in fere on females wyse" $(C$ 696), it is not. The antediluvians and the Sodomites are guilty not only of a sin against nature, but also of mimicking the sacred passion of a soul yearning for God and thus defiling it in a profane and sacrilegious manner. In this way, defilement reemerges as the ultimate common denominator of all three episodes of Cleanness and the precise nature of the uncleanness that the Maker hates with a fiery zeal whose extent, as the poem reiterates, no human mind could ever fathom.

\section{REFERENCES}

\section{PRIMARY SOURCES}

The Bible: Authorised King James Version 1998 New York: Oxford University Press.

Cawley, Arthur Clare - John J. Anderson (eds.)

1976 Pearl, Cleanness, Patience, Sir Gawain and the Green Knight. London: Dent.

\section{SECONDARY SOURCES}

Anderson, John J.

2005 Language and imagination in the Gawain-poems. Manchester: Manchester University Press.

Blanch, Robert J. - Miriam Youngerman Miller - Julian N. Wasserman (eds.)

1991 Text and matter: new critical perspectives of the Pearl-poet. Troy: Whitston.

Calabrese, Michael - Eric Eliason

1995 "The rhetorics of sexual pleasure and intolerance in the Middle English Cleanness", Modern Language Quarterly 56/3: 247-275.

Condren, Edward I.

2002 The numerical universe of the Gawain-Pearl poet: beyond phi. Notre Dame: University of Notre Dame Press.

Culler, Jonathan

1983 On deconstruction: theory and criticism after structuralism. Ithaca: Cornell University Press.

Keiser, Elizabeth B

1997 Courtly desire and medieval homophobia: the legitimation of sexual pleasure in Cleanness and its contexts. New Haven - London: Yale University Press.

Prior, Sandra Pierson

1994 The Pearl poet revisited. New York: Twayne. 
Wallace, David

1991 “Cleanness' and the terms of terror”, in: Robert J. Blanch - Miriam Youngerman Miller - Julian N. Wasserman (eds.), 93-104. 